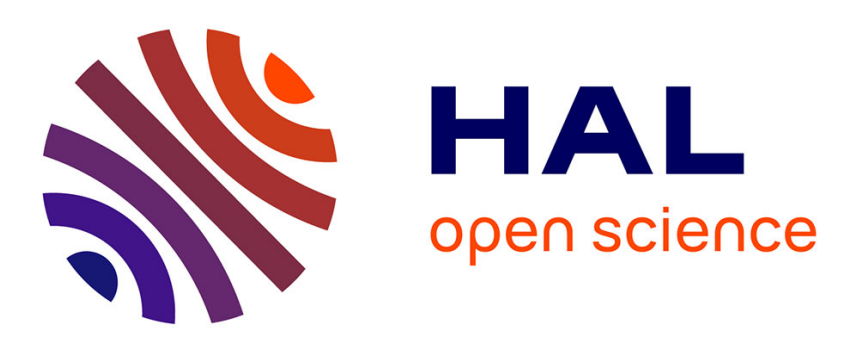

\title{
New K-Ar age determinations of Kilimanjaro volcano in the North Tanzanian diverging rift, East Africa
}

Philippe Nonnotte, Hervé Guillou, Bernard Le Gall, Mathieu Benoit, Joseph Cotten, Stéphane Scaillet

\section{To cite this version:}

Philippe Nonnotte, Hervé Guillou, Bernard Le Gall, Mathieu Benoit, Joseph Cotten, et al.. New K-Ar age determinations of Kilimanjaro volcano in the North Tanzanian diverging rift, East Africa. Journal of Volcanology and Geothermal Research, 2008, 173 (1-2), pp.99-112. 10.1016/j.jvolgeores.2007.12.042 . insu-00304458

\section{HAL Id: insu-00304458 \\ https://hal-insu.archives-ouvertes.fr/insu-00304458}

Submitted on 23 Jul 2008

HAL is a multi-disciplinary open access archive for the deposit and dissemination of scientific research documents, whether they are published or not. The documents may come from teaching and research institutions in France or abroad, or from public or private research centers.
L'archive ouverte pluridisciplinaire HAL, est destinée au dépôt et à la diffusion de documents scientifiques de niveau recherche, publiés ou non, émanant des établissements d'enseignement et de recherche français ou étrangers, des laboratoires publics ou privés. 
New K-Ar age determinations of Kilimanjaro volcano in the North Tanzanian diverging rift, East Africa.

Philippe Nonnotte ${ }^{\mathrm{a} *}$, Hervé Guillou ${ }^{\mathrm{b}}$, Bernard Le Gall ${ }^{\mathrm{a}}$, Mathieu Benoit ${ }^{\mathrm{a}}$, Joseph Cotten ${ }^{\mathrm{a}}$, Stéphane Scaillet ${ }^{\mathrm{b}}$

a CNRS-UBO, UMR 6538, IUEM, Place N. Copernic, 29280 Plouzané, France

b CEA-CNRS, UMR 1572, LSCE, Domaine du CNRS Bat. 12, Avenue de la Terrasse, 91198 Gif sur Yvette Cedex, France

* corresponding author: fax +33 (0) 298498760, e-mail: philippe.nonnotte@univ-brest.fr 


\section{Abstract}

The Kilimanjaro is the African highest mountain and culminates at $5895 \mathrm{~m}$ high. This huge volcanic edifice is composed of three main centres along a N110 ${ }^{\circ}$ E-striking axis (Shira, Kibo and Mawenzi from $\mathrm{W}$ to $\mathrm{E}$ ), and emplaced in a key area where a major $\mathrm{N} 80^{\circ} \mathrm{E}$-oriented volcanic lineament intersects a first-order NW-SE basement fault-like discontinuity. Seventeen K-Ar ages (on microcrystalline groundmass) acquired on lavas and intrusive facies from the three eruptive centres confirm that the Plio-Quaternary volcanicity of Kilimanjaro is clearly polyphased. The oldest phases of volcanic activity begun at $\sim 2.5 \mathrm{Ma}$ in the Shira vent and our data suggest that the latest important phases occurred around 1.9 Ma, just before the collapse of the Northern part of the edifice. Magmatic activity then shifted eastwards in the Mawenzi and Kibo twin centres where initial volcanism is dated at $\sim 1$ Ma. Two K-Ar ages obtained for the most recent Mawenzi rocks from the Neumann Tower-Mawenzi group (492 ka) and Mawenzi eruptive centre (448 ka), near the present summit, are linked to the final stage of edification for this centre. Whereas the eruptive activity ceased in the Mawenzi, it still continued on Kibo since sub-actual time. The oldest dated rocks from Kibo (482 ka) is obtained on a dyke from the Lava Tower group cropping out at $4600 \mathrm{~m}$ high. The main phase of magmatism on Kibo is recorded by two lava formations with a great spatial extension - the Rhomb Porphyry group and the Lent group - that have been emplaced in a short time interval at 460-360 ka (including two erosive stages) and 359-337 ka, respectively. Based on the dating of Caldera rim group lavas, it is shown that the edification of the present cone was accomplished in a period ranging from 274 to $170 \mathrm{ka}$. The new ages obtained for the main episodes of volcanic activity on Kibo appear to roughly coincide with the oldest known Quaternary glaciations. The interacting between eruptive phenomena and the ice cover is assumed to have played an important role in triggering collapse processes and associated lahars deposits. The last volcanicity, around 200-150 ka, is marked by the formation of the present summit crater in Kibo and the development of linear parasitic volcanic belts, constituted by numerous strombolian-type isolated cones on the NW and SE slopes of Kilimanjaro. These belts are likely to occur above deep-seated fractures that have guided the magma ascent, and the changes in their directions with time might be related to the rotation of recent local stress field.

Keywords: Kilimanjaro, East African Rift, K-Ar dating, volcanic history, Tanzania 


\section{Introduction}

The Eastern Branch of the East African Rift System (EARS) diverges southwards at $3^{\circ} \mathrm{S}$ from a single and narrow $(<50 \mathrm{~km})$ NS-trending volcanic rift valley in southern Kenya to form a $300 \mathrm{~km}$-wide three-arm rift system - the North Tanzanian Divergence (NTD hereafter) of Dawson (1992) - as approaching the Tanzanian craton (Ebinger et al., 1997). The abrupt change in style of rifting and magmatism coincides with a $\sim 50 \mathrm{~km}$-wide transverse volcanic chain extending $\sim$ at $\mathrm{N} 80^{\circ} \mathrm{E}$, i.e. perpendicular to the main rift axis, over more than $200 \mathrm{~km}$ from the Ngorongoro crater to the Kilimanjaro volcano eastwards. South of the so-called Ngorongoro-Kilimanjaro Volcanic Belt (NKVB in the text), the only evidence of rifting at the surface are a series of basement tilted blocks and associated half-graben basins. There, the rapid and nearly total disappearance of magmatism indicates that the thermal influence of the mantle plume responsible for the extensive volcanic complexes in the Kenya rift further $\mathrm{N}$ is no longer effective over the North Tanzanian rifted domain. The NKVB comprises numerous ( 20) individual volcanic edifices ranging in age from 8 Ma to Present (Dawson, 1992). Existing radiometric dataset have been preferentially devoted to volcanic rocks in the central and western parts of the NKVB that connect the S Kenya axial trough $(\mathrm{N})$ and the EyasiManyara rift arms (S) (Foster et al., 1997). Very few ages determinations have been yet obtained about the easternmost part of the NKVB that lies in an off-axis position with regards to the main rifted domain in Kenya (Fig. 1). Therefore, no accurate age migration of magmatism has been so far established throughout the NKVB, as a whole. Paradoxally, recent radiometric dating have not been applied to Mount Kilimanjaro though forming the most prominent volcanic construction of the East African Rift. Compiling the seven published ages for the three cones (Shira, Kibo and Mawenzi) forming Kilimanjaro (Evernden and Curtis, 1965; Baker et al., 1971; Evans et al., 1971; Bagdasaryan et al., 1973; Wilkinson et al., 1986) shows a polyphased volcanic history over the past $2 \mathrm{Ma}$, between $\sim 2.3$ and $\sim 0.17 \mathrm{Ma}$ (Dawson,1992), but given the uncertainties about these data (for example, $2.3 \pm 0.4 \mathrm{Ma}$, Bagdasaryan et al., 1973), it is difficult to establish a genetic link between the Shira, Mawenzi and Kibo magmatic activities.

On the basis of recent field work campaigns (October 2003 and January-March 2005) and newly-acquired unspiked K-Ar ages determinations of effusive and extrusive mafic volcanics from Kilimanjaro, the main purposes of the present study are first to precise, in terms of duration, temporal/spatial distribution and emplacement mechanisms, each successive magmatic phase that finally led to the built-up of the Kilimanjaro polyphased volcano. Some 
assumptions about basement structural control and stress field conditions during the youngest parasitic volcanic episode are also presented. Most of the representative volcanic formations of Kilimanjaro have been sampled on the southern flank of the edifice and seventeen rock samples have been selected and dated by Unspiked K/Ar method. It should be noticed that the petrological and geochemical characteristics of dated lavas and dykes are not detailed in this work but will be extensively discussed in an other paper. However, the range of petrological compositions of Kilimanjaro lavas (unpublished data) is illustrated in the Total-Alkali-Silica classification diagram (Fig. 3) of Le Bas et al. (1986) and allow us to distinguish clearly the three main centres and the final parasitic stage.

At a greater scale, compiling existing radiometric ages about volcanic edifices in the NTD allows us (1) to deduce the easterly shift of magmatism along the NKVB during Neogene time, and (2) precise the tectono-magmatic significance of Kilimanjaro with respect to the North Tanzanian rift framework.

\section{Geological setting}

\subsection{Tectono-magmatic rift framework}

The 50 x $200 \mathrm{~km}$ NKVB comprises numerous volcanic edifices, and their extensively distributed effusive and air-fall material, that were emplaced during the time interval 8 MaPresent (Evernden and Curtis, 1965; Baker et al., 1971; Evans et al., 1971; Bagdasaryan et al., 1973; Macintyre et al., 1974, Wilkinson et al.,1986, Dawson, 1992, Foster et al., 1997) close to, or following in part, a fundamental lithospheric-scale discontinuity between Proterozoic terranes of the Mozambique Belt and Archaean cratonic blocks involving the Masai nucleus (Fig. 1).

The 2D-map structural pattern of the NTD is dominated by variously-trending volcanic axes, outlined by individual edifices or eruptive centres, which indicate a dominant fissure control at depth (Fig. 1). A NE-SW trend is marked to the $\mathrm{W}$ by a $\mathrm{N} 40^{\circ} \mathrm{E}$ volcanic segment, enclosing ten major shield volcanoes of the Crater Highlands, that passes laterally to the SW into the $>100 \mathrm{~km}$-long Eyasi fault system. Further E, the Tarosero, Essimingor and Burko volcanoes are also aligned at NE-SW in the southern prolongation of the Magadi-Natron NS axial trough in $\mathrm{S}$ Kenya. A $\mathrm{N} 80^{\circ} \mathrm{E}$ trend is exclusively expressed by three aligned volcanoes (Monduli, Meru and Kilimanjaro) along the eastern part of the NKVB. Lastly, NW-SE axes 
are outlined by the fissure volcanism associated with the parasitic activity on the SE flank of Kilimanjaro and on the Chyulu Hills that both represent the most external off-axis magmatism in the NKVB. The arrangement of dated volcanic features in the NTD into tectono-magmatic lineaments supplies additional insights on its structural history during the onset of magmatism. The compilation of existing radiochronological ages (Evernden and Curtis, 1965; Baker et al., 1971; Evans et al., 1971; Bagdasaryan et al., 1973; MacIntyre et al., 1974, Wilkinson et al.,1986, Dawson, 1992, Foster et al., 1997) reveal a rough E-W age progression which is due to a shift of magmatic activity eastwards in the time range 5.0 Ma- Present. The precursor volcanics in the NTD are nephelinites, 8.1-7.3 Ma in age, emplaced in the Essimingor region (Bagdasaryan et al., 1973), but the main volcanic activity started at 5.0 Ma and involved three successive magmatic stages until recent times.

From 5.0 to $2.5 \mathrm{Ma}$, magmatism was still persistent in the Essimingor area, but shifted for the first time to the $\mathrm{W}$, at the southern extremity of the incipient Eyasi oblique belt where the Lemagrut, Sadiman and Manyara edifices were erupted intermittently in the time range 5.54.5 Ma (Bagdasaryan et al., 1973 ; Foster et al., 1997). In the time period 3.7-2.5 Ma, renewal of magmatism was marked by ongoing activity in older volcanic areas (Lemagrut, Sadiman), and its lateral spreading over intact domains such as (1) the central (Ngorongoro) and NE (Mosonik) parts of the Eyasi volcanic belt, and (2) the Engaruka oblique depressed zone in the SSE prolongation of the Magadi-Natron axis (Bagdasaryan et al., 1973).

Dramatic changes in magmatism distribution took place at around 2.5 Ma in the developing NTD. To the W, magmatism waned markedly at the SW extremity of the Eyasi belt whereas new eruptive centres were emplaced further NE (Olmoti) up to the intersection with the Magadi NS axis (Manega, 1993 ; Foster et al., 1997). In the Essimingor central domain, ongoing volcanism shifted eastwards along the NE-SW-trending Tarosero axis, as well as in the Engaruka and Ketumbeine areas (Bagdasaryan et al., 1973; MacIntyre et al., 1974). Lateral widespread of the volcanic province to the E also expressed by the built up of a new magmatic segment, about $100 \mathrm{~km}$-long, enclosing the Monduli, Shira edifices and Mt Meru area (Wilkinson et al., 1986 ; Le Gall et al., accepted). From 1.5 Ma to Present, there was a nearly total abandonment of magmatism throughout the Eyasi transverse belt to the W. Only sporadic volcanic activity occurred within the Ngorongoro crater by local fissure-type basaltic eruptions (Le Gall et al., accepted). Along the Manyara-Balangida N20-N60 ${ }^{\circ} \mathrm{E}$ axis, the Kwaraha and Hanang isolated eruptive centres were synchronously emplaced at $\sim 1.5 \mathrm{Ma}$ (Bagdasaryan et al., 1973), hence forming the southernmost surface expression of synrift magmatism in the eastern branch of the EARS. In the central domain, magmatism spread over 
a larger province including the Embagai, Gelai and Burko volcanoes (Manega, 1993). The easterly shift of magmatism persisted along the NKVB until recent time by the emplacement of lavas in the Mt Meru, Kilimanjaro and Chyulu Hills sectors (Saggerson, 1963; Haug and Strecker, 1995, Le Gall et al., accepted) with the edification of these volcanoes and the emplacement of fissure type parasitic tuff cones.

\subsection{Geological features of Mount Kilimanjaro}

On the simplified structural map (Fig. 1), Mount Kilimanjaro is located in a key-area where the $\mathrm{N} 80^{\circ}$ E-oriented axis of the NKVB intersects the NW-SE trace of the ASWA basement shear zone (Chorowicz, 1989; Coussement, 1995) that continues further SE by the Pangani rift arm (Fig. 1). Kilimanjaro is a 40 x $60 \mathrm{~km}$ elliptic edifice with three centres equally spaced along a $\mathrm{N} 110^{\circ} \mathrm{E}$-striking axis (Fig. 2A) and resting on a floor composed of Middle to Late Tertiary erosion products of surrounding Precambrian basement rocks of the Mozambique Belt (Dawson, 1992). The contrasted morphology and volcano-stratigraphy of the three centres both testify to an intricate and polyphased volcanic history which is briefly commented below. The volcano-stratigraphic template used in this work (see the sketch geological map of Figure 2B) is chiefly derived from the nomenclature established by previous authors (Downie et al., 1956, 1965; Downie and Wilkinson, 1972), further completed by new petrological and geochronological data obtained during this study on the southern flank of Kilimanjaro. The initially sub-circular cartographic arrangement of the Shira and Mawenzi units is still recognizable on the map of Figure 2B though having been subsequently obscured by younger formations from Kibo and by numerous parasitic cones.

Shira forms a broad upland plateau at about $3800 \mathrm{~m}$ with higher summits culminating at 3962 $\mathrm{m}$. The eastern collapsed part of its crater rim is severely degraded by erosion and partly overlapped by Kibo formations. Volcanic rocks of Shira are mainly basic lavas with considerable amounts of pyroclastic material. The so-called Platzkegel agglomerate in the centre of the caldera, is composed by a heterogeneous assemblage of basaltic breccias and thin lava flows later intruded by few dolerite and essexite dykes. This structure can be interpreted as either a protrusion or a vent infilling (Downie and Wilkinson, 1972). The Shira Ridge group mainly comprises pyroclastic material ranging from basanites to tephrites (Fig. 3) with additional basalts and nephelinites (Downie and Wilkinson, 1972). These breccias are cut by an important radiating dyke swarm involving steep to subvertical dykes 
( 1 m-thick, Fig. 5A) of basanitic composition with doleritic texture (Fig. 4A) and a few intrusions of essexite.

Located to the East, Mawenzi is the remnant of a volcanic cone forming a horse shoe-shaped ridge opened to the NE and culminating at $5149 \mathrm{~m}$. Its present-day tower-like morphology results from a dense radial mafic dyke swarm (>500 intrusions, Fig. 5B) deeply incised by erosion. They can be grouped into one set compositionally homogeneous intrusive rocks with basaltic to trachybasaltic affinities (Fig. 3 and Fig. 4B), cutting through all the Mawenzi formations. The Neumann Tower-Mawenzi group comprise numerous lava flows, with similar affinities, that overlie earlier eruptive products from the main vent, over the western slopes. The Mawenzi eruptive centre are mainly constituted by pyroclastic breccias and blocky lava flows.

The central edifice Kibo is the main peak of Kilimanjaro (5995 m). It is characterized by a cone-shaped morphology with slopes around $30^{\circ}$ overhanging the 'Saddle' plateau between Kibo and Mawenzi peaks. Its summit is composed of a $2.5 \mathrm{~km}$ caldera enclosing a $900 \mathrm{~m}$ wide inner crater and the smaller 200 m-wide 'Ash pit'. The volcano-stratigraphy of Kibo is rather more complicated and results principally from extrusion of undersaturated rocks, and to a lesser extent from emplacement of pyroclastic material. From bottom up, the Kibo volcanic pile is composed as follows: (1) The Lava Tower group is dominated by lavas ranging from phono-tephrites to tephri-phonolites (Fig. 3) with tabular sodic feldspar phenocrysts (Fig. 4C). (2) The Rhomb Porphyry group is the most distinctive formation of Kibo with tephriphonolite (Fig. 3) to phonolite lavas characterized by rhomb mega-phenocrysts of sodic feldspars (30-40 mm-long, Fig. 4D). (3) The Lent group involves aphyric phonolite (Fig. 3 and Fig. 4E) lava flows, commonly underlain by basal obsidian horizons. It spreads widely on the northern and southern flanks as a flank eruption unit. (4) The Caldera Rim group is constituted by porphyric tephri-phonolite to phonolite lavas (Fig. 3) containing nepheline and sodic feldspar phenocrysts (Fig. 4F). It principally erupted from the present crater of Kibo and from several adventive centres such as the 'Lava Tower' protrusion (Fig. 5C). (5) The Inner Crater group occurs in the present summit crater floor and overflowed to the N. It represents the last volcanic activity on Kibo. It is predominantly composed of phonolite lava flows (Fig. 4G) where aegyrine phenocrysts can be found (Downie and Wilkinson ,1972). No historical eruptions have been recorded on Kibo that still retains heat, with a fumarolic activity at its summit crater, and may not yet be completely extinct.

The NW and SE flanks of Kilimanjaro are largely obscured by a large number $(>250)$ of small cinder cones of strombolian scorias (Fig. 5D) and associated lava flows (from picro-basalts to 
trachybasalts, Fig. 4H, with also basanites and ankaramites, Fig. 3) that are concentrated along three nearly parallel belts $\left(\mathrm{N} 120-140^{\circ} \mathrm{E}\right)$, the Kilema and Rombo zones to the SE and the $\mathrm{Ol}$ Molog zone to the NW, that die out at an altitude of about $4000 \mathrm{~m}$.

\section{The unspiked K/Ar technique and samples}

A total of seventeen samples, including both extrusive (thirteen) and intrusive (four) facies from three eruptives centres, have been selected for unspiked K-Ar ages determinations. Despite its restricted geographical location over the southern flank of Mount Kilimanjaro, the sampled collection which was guided by field geology and mapping, to provide the timing and duration of each volcanic unit, is representative of the entire magmatic succession to further characterize each individual formation. This choice is reinforced by the nearly symmetrical mapped distribution of most of the volcanic series on both flanks of the Kilimanjaro.

One of the main assumptions, when using the K-Ar system is the "closed system" one. Consequently, to reduce if not to avoid disturbances of the K-Ar clock related to loss or gain of ${ }^{40} \mathrm{~K}$ and or ${ }^{40} \mathrm{Ar} *$, only rocks with little or no traces of alteration were selected for dating. Degree of alteration was estimated from macroscopic and microscopic observation. Loss On Ignition (LOI, Table1) was determined along with the major element analyses (unpublished data) and range from $-0.35 \%$ to $1.8 \%$. The thin sections of the three samples with LOI $>1 \%$ (05KI14, 05KI24 and 05KI29) were carefully observed to check the groundmass alteration, which appears systematically devoid of alteration products (Fig. 4). However, we can notice that giant sodic feldspars phenocrysts of samples $05 \mathrm{KI} 14$ and $05 \mathrm{KI} 24$ present a classical alteration in sericite, and that sample 05KI29 present amphibole phenocrysts. The determination of LOI was made on whole-rock powder including the phenocrysts. These observations reinforce our choice to eliminate the phenocrysts from the groundmass prior to age determinations.

The samples were crushed, sieved to $0.25-0.125 \mathrm{~mm}$ size fraction and ultrasonically washed in acetic acid $\left(\mathrm{C}_{2} \mathrm{H}_{4} \mathrm{O}_{2}\right)$. Potassium and argon were measured on the microcrystalline groundmass. Phenocrysts and xenocrysts, which are potential carriers of extraneous ${ }^{40} \mathrm{Ar}$ (including excess and inherited components) were eliminated using magnetic, gravimetric, and visual hand picking separation (Guillou et al., 1996). This process increases the K content as well as the percentage of radiogenic argon over the bulk rock values, and removes at least 
some potential sources of systematic error due to the presence of excess ${ }^{40}$ Ar* (Laughlin et al., 1994) known to occur in olivine and pyroxene.

$\mathrm{K}$ was analyzed by ICP-AES (Cotten et al., 1995) with a relative precision of $1 \%$. A description of the unspiked technique and the instrument used for Ar measurements is presented elsewhere (Charbit et al., 1998). The unspiked technique differs from the conventional isotope dilution method in that the argon extracted from the sample is measured in sequence with purified aliquots of atmospheric argon, at the same working gas pressure in the mass-spectrometer. This allows one to suppress mass discrimination effects between the atmospheric reference and the unknown (i.e. sample), and allows quantities of radiogenic ${ }^{40} \mathrm{Ar} *$ as small as $0.14 \%$ to be detected on a single-run basis (Scaillet and Guillou, 2004). Prior to analysis, the freshness of the groundmass aliquots was checked through microscopic observations using a binocular microscope. These observations confirmed along with the LOI values the freshness of the dated samples. Argon was extracted from 1 to $2.0 \mathrm{~g}$ of this unaltered groundmass samples by radio frequency induction heating in a high-vacuum glass line and purified with titanium sponge and SAES Zr-Al getters. Isotopic analyses were made on ${ }^{40} \mathrm{Ar}$ quantities ranging from $1.0 \times 10^{-11}$ moles to $5.0 \times 10^{-11}$ moles, using a $180^{\circ}, 6 \mathrm{~cm}$-radius mass spectrometer with an accelerating potential of 620 Volts. The spectrometer was operated in a semi-static mode; data were measured on a double faraday collector in sets of 100 using a 1 second integration time. The sensitivity of the mass spectrometer is about $5.1 \times 10^{-15}$ moles $/ \mathrm{mV}$ with amplifier background of $0.075 \mathrm{~V}$ for ${ }^{40} \operatorname{Ar}\left(10^{9}\right.$ ohms resistor $)$ and $5.75 \mathrm{mV}$ for ${ }^{36} \operatorname{Ar}\left(10^{11}\right.$ ohms resistor). The atmospheric isotopic composition of the procedural blanks was checked by repeated processing of zero-age samples.

The manometric calibration is based on periodic, replicate determinations of international dating standards of known K-Ar age using the same procedure as for the unknowns (Charbit et al., 1998). The processed weight of standard usually ranges between 80 to $100 \mathrm{mg}$. At these levels, possible heterogeneity of standard split is no longer an issue. Our calibration procedure allows the total ${ }^{40} \mathrm{Ar}$ content of the sample to be determined with a precision of about $\pm 0.2 \%$ $(2 \sigma)$. Standards used include LP-6 (127.8 \pm 0.7 Ma: Odin et al., 1982) and HD-B1 (24.21 \pm 0.32 Ma: Fuhrmann et al., 1987; Hess and Lippolt, 1994; Hautmann and Lippolt, 2000). At the $95 \%$ confidence level, the values adopted here are consistent with those obtained for several ${ }^{40} \mathrm{Ar} /{ }^{39} \mathrm{Ar}$ standards intercalibrated against biotite GA-1550 (Renne et al., 1998; Spell and McDougall, 2003). 
The unspiked K-Ar method is preferred for dating these Quaternary volcanic rocks (Guillou et al., 1998) because it allows a precise and accurate determination of low percentages of radiogenic argon. Nevertheless, the unspiked technique relies, as does the conventional one, on the fundamental assumptions of K-Ar dating (Dalrymple and Lanphere, 1969). Consequently, to check the reliability and range of effectiveness of this technique which has been extensively used with success to date recent volcanic edifices (De Rosa et al., 2003; Guillou et al., 2000, 2004a, 2004b, 2005, Carracedo et al., 2007), comparative (unspiked KAr and ${ }^{40} \mathrm{Ar} /{ }^{39} \mathrm{Ar}$, unspiked K-Ar and ${ }^{14} \mathrm{C}$ ) dating of Quaternary samples (Guillou et al., 1998, Ackert et al., 2003, Singer et al., 2004, Guillou et al., 2004c, Carracedo et al., 2007) were performed. Consequently, in this work we followed the same sample preparation and technical procedure than the ones described in details in Guillou et al. (2004b) and Charbit et al. (1998). In addition, to minimize, if not eliminate the probability of erroneously old ages owing to inherited ${ }^{40} \mathrm{Ar}$ trapped in phenocrysts and/or xenocrysts densitometric and magnetic separation of pure aliquots of groundmass were performed. Despite this sample preparation procedure, the main unknown in the unspiked K-Ar method remains the isotopic composition of the initial argon in the samples. In other terms, we must assume that, at the time of formation, the ${ }^{40} \mathrm{Ar} /{ }^{36} \mathrm{Ar}$ ratio of the sample was the modern atmospheric value (295.5). As a result, the calculated errors, which are the analytical errors, may in some cases be lower than the real errors if the dated sample contained excess ${ }^{40} \mathrm{Ar}^{*}$. To moderate this, we mention that excess ${ }^{40} \mathrm{Ar}^{*}$ is usually considered insignificant in subaerial lava flows (Kelley, 2002) and mainly restricted to potassic magmas (Villa, 1991), although it may be present in the groundmass of some basaltic samples (Guillou et al., 2000). However, such abnormal results may be identified by their incompatibility with the general stratigraphy of the volcanic edifices. Consequently only samples which were clearly assigned to a formation or to a volcanic unit were retained for dating in order to perform a direct comparison between the radiometric ages and the field stratigraphy. This is a primary check on the geological significance of the ages.

The geological characteristics of dated samples are presented in Table 1, and their GPS locations are shown on Figure 2B.

- The two samples from the Shira Ridge group are (1) a subvertical basic dyke (05KI08B, Fig5A) and (2) a blocky lava flow (05KI07C) from its country-rocks.

- Two trachybasaltic samples collected from Mawenzi centre are (1) a lava flow of the Neumann Tower-Mawenzi group (05KI43B) resting on a glacial erosion surface, and (2) a 
basic dyke (05KI45, Fig. 5B) which is part of the important swarm intruding the pyroclastic breccias of the Mawenzi eruptive centre.

- Eleven samples were collected on the southern flank of Kibo. They consist, from bottom up in the stratigraphic order, of: (1) One subvertical phono-tephritic dyke of the Lava Tower group (05KI14). (2) Lava flows (x 5) of the Lent group formation (05KI05A, 05KI29, $05 \mathrm{KI} 30,05 \mathrm{KI} 32$ and $05 \mathrm{KI} 37$ ) resting on a glacial erosion surface affecting the top of lavas from the Rhomb porphyry group. (3) One lava (05KI03), inferred to belong to the Lent group because of its petrographic and geochemical affinities, but in apparent disagreement with its cartographic location in a crest above deeply incised Lava Tower group formations. (4) Sampled rocks from the Caldera Rim group (x 4) consist of the rim of the 'Lava Tower' neck-like protrusion (05KI17) which fed one of the most important flows of the Kilimanjaro (Fig. 5C), together with lava flows (x 3) emitted from various eruptive vents on Kibo. Rock sample $05 \mathrm{KI} 12$ is from a formation overlying an erosion surface affecting the Lava Tower group rocks; 05KI24 is part of a lava flow resting on top of the 'Kibo Barranco' western wall; lastly, 05KI38B is a glassy phonolite extracted from the lower chilled margin of a lava flow cropping out at Stella Point, e.g. close to the Kibo summit.

- Two basanitic lavas were sampled in the formations associated with the late parasitic activity. 05KI41B was taken in a 15 m-thick lava flow, emplaced on the 'Saddle' from the strombolian eruptive centres, between Kibo and Mawenzi. 03TZ42B was sampled in a poorly-exposed prismatic lava flow in the Marangu area (Rombo zone).

\section{Unspiked K/Ar data}

Our new Unspiked K-Ar data are presented in Table 1 and Figure 2B, and compared to previously published ages.

- Both the lava sample (05KI07C) and one of its possible feeder dyke (05KI08B) from Shira yield nearly similar ages of $1927 \pm 41 \mathrm{ka}$ and $1975 \pm 42 \mathrm{ka}$ respectively, within the analytical uncertainty. These two ages are coherent at the $2 \sigma$ level, and statistically similar to the very low precise age of $2300 \pm 400 \mathrm{ka}$, previously obtained by Bagdasaryan et al. (1973) on a sample from the western slopes of Shira. They might be related to the latest phases of activity in the Shira centre, but no clear link can be established with the emplacement of the Platzkegel agglomerate. 
- The two Mawenzi samples (05KI43B and 05KI45) yield similar ages of 492 $\pm 11 \mathrm{ka}$ and $488 \pm 11 \mathrm{ka}$, respectively. They are consistent with the Evernden and Curtis (1965) rough dating of Mawenzi trachybasalts $(\sim 514 \mathrm{ka})$, but significantly younger than the $950 \pm 50 \mathrm{ka}$ age published by Bagdasaryan et al. (1973) for a sample from the eastern slopes. On the basis of field observation and cartographic arrangement, the pyroclastic products of the Mawenzi eruptive centre can be considered as slightly contemporaneous to the major dyke swarm. The petrological homogeneity and the temporal relationships between the lavas of the Neumann Tower-Mawenzi group and the intrusive facies of the Mawenzi eruptive centre both show that these two units were produced during the same volcanic activity period, with the dyke swarm probably feeding the lava formations.

- The dyke from the Lava Tower group (05KI14) is dated at $482 \pm 10 \mathrm{ka}$, clarifying the $\sim 463$ ka proposed by Evernden and Curtis (1965) for a phonolite of the same suite. This volcanic suite is the oldest formation actually exposed on Kibo, in large valleys on the western upper flank of the main cone.

- The ages for rocks belonging to the Lent group (05KI05A, 05KI29, 05KI30, 05KI32 and 05KI37) range from $359 \pm 8 \mathrm{ka}(05 \mathrm{KI} 05 \mathrm{~A})$ to $337 \pm 7 \mathrm{ka}$ (05KI30). Sample 05KI03A shows an age of $348 \pm 7 \mathrm{ka}$, falling in the same range of lava ages related to the Lent group. The large spatial distribution of this formation, at the scale of the entire edifice, in addition to the reduced time interval for its emplacement, both suggest that the lava was emitted from four separate flank eruptive centres (Downie and Wilkinson, 1972) during a short period of intense volcanic activity.

- The Caldera Rim group samples display ages ranging from $274 \pm 6 \mathrm{ka}$ (05KI17) to $209 \pm 5 \mathrm{ka}(05 \mathrm{KI} 24)$. 'Stella point' sample $05 \mathrm{KI} 38 \mathrm{~B}$ gives an age of $227 \pm 5$ ka that falls in the range $\sim 260-170$ ka previously proposed by Wilkinson et al. (1986) from anorthoclase phenocrysts. Although age determinations of lavas from the present caldera of Kibo have not been obtained, our data on the lavas of Caldera Rim group confirm that the collapse of the summit crater and the emplacement of the phonolites belonging to the Inner Crater group formation are $<200 \mathrm{ka}$.

- Samples associated with the latest parasitic phase (05KI41B and 03TZ42B) yield ages of $165 \pm 5 \mathrm{ka}$ and $195 \pm 5 \mathrm{ka}$, respectively. These two ages are similar to dates of $190 \pm 10 \mathrm{ka}$ and $170 \pm 10 \mathrm{ka}$, relevant to anorthoclase phenocrysts on samples from the caldera rim of Kibo summit (Wilkinson et al., 1986). It thus appears that the last time of activity on Kibo summit is very recent, and probably contemporaneous to the phases of parasitic activity. 


\section{Volcanic history and implications}

On the basis of existing radiometric dataset, it is still difficult to ascertain the age of the first volcanic activity of Kilimanjaro as a whole. Our new set of ${ }^{40} \mathrm{~K}-{ }^{40} \mathrm{Ar}$ data permits to better constrain the time framework previously established (Evernden and Curtis, 1965; Baker et al., 1971; Evans et al., 1971; Downie and Wilkinson,1972; Wilkinson et al.,1986), with emphasis on the youngest magmatic events that are recorded by rocks largely exposed on the upper slopes of the three edifices. Three successive volcanic stages are distinguished and referred to as the main edifices of Kilimanjaro, respectively. They slightly overlap in time for the recent activities of the Mawenzi and Kibo magmatic centres (Fig. 6).

\subsection{The Shira stage}

Shira is the oldest volcanic centre of Kilimanjaro. Given the large uncertainty (0.4 Ma) attached to the age of $2.3 \mathrm{Ma}$ obtained from conventional K-Ar whole-rock dating by Bagdasaryan et al. (1973), the early volcanic stages of Shira cannot be unequivocally ascertained. Nevertheless, this age suggests that the beginning of volcanic activity for Shira at around 2.5 $\mathrm{Ma}$ is synchronous to others magmatic centres of the NKVB further W (Ngorongoro and Monduli-Meru areas, see Fig. 1) (Macintyre et al., 1974; Dawson, 1992). From petrological and structural homogeneities of intrusive rocks along the caldera rim (Downie and Wilkinson, 1972), the age of $\sim 1.9 \mathrm{Ma}$ obtained in the present work for the basanitic dyke 05KI08B is also likely to be applied to the entire radial swarm cutting through all the formations of the Shira Ridge group, and is further indicative of the final phases of Shira activity. Such radial dyke swarms are typically emplaced during the volcano inflating step at the beginning of an eruptive phase (Chadwick and Howard, 1991; Walker, 1999). The dominant breccia products of the Platzkegel agglomerate might have filled the former eruptive vent of Shira during this final eruptive event. The massive collapse of the Northern wall of Shira likely occurred at the end of this important volcanic activity phase around 1.9 Ma during a massive explosive eruption. The youngest evidence for magmatic activity are linked to the emplacement of numerous mafic dykelets and minor nephelinitic protrusions cutting through the Platzkegel agglomerate. The onset of magmatic activity in Shira is followed by a long period of quiescence and erosion (Fig. 6) that resulted in the degradation of the volcanic construction and the corresponding deposit of volcanoclastic sequences, subsequently overlain by Kibo lavas, in the present caldera. 


\subsection{The Mawenzi stage}

Nearly 900 ka. after the Shira collapse, renewed volcanism shifted to the east in the Mawenzi magmatic centre where initial eruptions are dated at 0.95 $\pm 0.05 \mathrm{Ma}$ (Bagdasaryan et al., 1973). The end of magmatism took place at around 492 - $488 \mathrm{ka}$ as evidenced by our dating of both extrusive and intrusive rocks of the Neumann Tower-Mawenzi group and Mawenzi eruptive centre (05KI43B and 05KI45). Indeed, the two eruptive centres forming the Mawenzi edifice were active for a short time interval of 500 - 550 ka (Fig. 6), marked by a lateral shift of eruptions from the adventive 'Neumann Tower' centre to the Mawenzi central cone (Downie and Wilkinson, 1972). The end of eruption processes coincided with an important gravity sliding - forming the 'Great Barranco' - and associated laharic breccias in the eastern slopes of the edifice. This catastrophic event is synchronous to the emplacement of a syenitic intrusion in the centre of the main Mawenzi cone (Downie and Wilkinson, 1972) that might have triggered vertical uplift and induced slope instability. Glaciers are known to have developed during the First glaciation event which is approximately dated at $500-460 \mathrm{ka}$ (Shanahan and Zreda, 2000), i.e. contemporaneously with the main magmatic phase of Mawenzi. Therefore, the role of melting ice cap on initiation of lahar deposits and gravity sliding cannot be totally ruled out.

\subsection{The Kibo stage}

The age of initial construction of Kibo is matter of debate, but according to the dating of an olivine basalt from the Amboseli area on the northern side of Kilimanjaro, it might have started at c. 1 Ma (Baker et al., 1971), contemporaneously with the beginning of Mawenzi activity (Fig. 6). The oldest lavas sampled on Kibo during this work are from sequences of the Lava Tower group occurring at about 4600 m-high. They yield age of $482 \pm 10 \mathrm{ka}$ (05KI14), concordant with existing age of $\sim 463 \mathrm{ka}$ (Evernden and Curtis, 1965), and close to those obtained here on Mawenzi rocks sampled nearly at the same altitude. It is thus suggested that the two adjoining magmatic centres yet reached at that time quite similar mature edification stages. Although, lavas of the Rhomb porphyry group are still undated, they were probably emitted in a short time period during an intensive volcanic activity phase, given their great aerial distribution on the slopes of Kilimanjaro. Our results show that the maximum age bracket for this important eruptive event is $482 \pm 10 \mathrm{ka}-359 \pm 8 \mathrm{ka}$, including two erosive 
episodes (Fig. 6). Indeed, lavas of the Rhomb porphyry group rest over an erosion surface, on top of the underlying Lava Tower group formations, that cannot be easily related to any known Quaternary glaciation episode (Downie and Wilkinson, 1972). On the opposite, the top of the Rhomb porphyry group formations is affected by an important glacial erosion event clearly linked to the Second glaciation, approximately dated at $>360$ ka by cosmogenic ${ }^{36} \mathrm{Cl}$ method of moraines boulders (Shanahan and Zreda, 2000). The phonolitic lavas of Lent group, assumed to have been emitted from four main flanks centres over the slopes of Kibo in the time-interval $359 \pm 8 \mathrm{ka}-337 \pm 7 \mathrm{ka}$, overlaid this second erosional surface, and thus demonstrate that the age of the Second glaciation is $>359 \pm 8$ ka (Fig. 6). In addition to three previously published ages (Wilkinson et al., 1986), our new dating make the Caldera Rim group the best dated formation of the whole Kilimanjaro. The time emplacement of this group is between $274 \pm 6$ and $170 \pm 10 \mathrm{ka}$, with corresponding lava sequences emitted from the present summit and several centres on the flanks of the main cone of Kibo. According to Downie and Wilkinson (1972), the collapse creating the great 'Kibo Barranco' and the Kibo lahar might have occurred concomitantly at the final stage of this major volcanic episode. The driving mechanism for this landslide on the southern flank of Kibo is likely to be the intrusion of the syenitic plug present at the base of the summit cone (Downie and Wilkinson, 1972). Although evidence for the Third glaciation are scarce on Kibo (Osmaston and Harrison, 2005), Downie et al. (1965) considered this paleo-climatic event as slightly contemporaneous to the emplacement of the Caldera Rim group lavas (Fig. 6). As stated above about collapse and induced gravity deposits on Mawenzi, surficial water supply from melting ice cap could have also played a key-role in the formation of the 'Kibo Barranco' and associated Kibo lahar. Dating of phonolites from the Caldera Rim group sampled on top of the Kibo summit rim shows that the construction of the present caldera, as well as the extrusion of the Inner Crater group lava flows, were both achieved in the last $200 \mathrm{ka}$.

To summarize, the volcanic activity of Kibo during the last $500 \mathrm{ka}$ appears extremely polyphased, involving erosive periods that alternated with intensive volcanic activity during which huge volumes of lavas were emitted over great surficial areas. The numerous erosive phases correspond to arrests in the eruptive processes and are likely to be associated to glacial periods (Second glaciation). These volcanic-erosive process cycles show a rough periodicity of 50 - $70 \mathrm{ka}$. The fact that both volcanic and glacial processes could occurred in the same time, as evidenced for the emplacement of Caldera Rim group and the Third glaciation, 
played an important role in the dynamical expression of eruptive phenomena with the formation of laharic breccias associated with large-scale landslides. It also appears that the latest phases of activity on Kibo, and at a greater scale on the Kilimanjaro edifice as a whole, are contemporaneous to those observed on the Meru volcano, further West (Fig. 1) (Wilkinson et al., 1986).

\subsection{Parasitic stage and structural inheritance}

The final stages of edification in Kibo, with the emplacement of phonolites of Caldera Rim group and Inner Crater group at the summit, is contemporaneous with the swarms of strombolian-type parasitic cones over the NW and SE flanks of Kilimanjaro. Lavas emitted from these adventive centres range from picrobasalts to trachybasalts + basanites and ankaramites, and are thus less differentiated than the phonolitic material erupted from Kibo (Fig. 3). The 2D-map arrangement of these young volcanic centres provides some clues about the role of structural inheritance and changing stress field on the final architecture of Kilimanjaro. Firstly, the alignment of the parasitic cones within two narrow prominent 10-20 $\mathrm{km}$-long ridges, trending at $\mathrm{N} 150^{\circ} \mathrm{E}$ (Rombo belt) and $\mathrm{N} 160^{\circ} \mathrm{E}$ (Kilema belt), throughout the SE flank of Kilimanjaro (up to an altitude of 4500m) indicates the control of deep-seated fractures on the ascent of magma up to the surface during recent times. The inferred fracture pattern is likely to be part of the ASWA shear zone that extends at NW-SE in the Proterozoic basement of Kenya, NW of Kilimanjaro. The location of the Mawenzi and Kibo magmatic centres at the northwestern ends of these volcanic lineaments further suggests that the corresponding magmatic chambers at depth might have occurred at the intersection of (1) ASWA-type NW-SE fractures, and (2) a second crustal-scale discontinuity, following the $\mathrm{N} 80^{\circ} \mathrm{E}$ northern margin of the Masai craton (Fig.1) that also controlled the orientation of the NKVB as a whole. It is thus proposed that the volcanic sequences produced in the main Kibo cone (Inner Crater group) originated from the replenishment of the crystallizing magmatic chamber by laterally-migrating fissural-type basic magmas, in agreement with a mechanism applied by Wolff (1985) for volcanics in the Tenerife Island. Secondly, the new age determinations of $195 \pm 5 \mathrm{ka}$ and $165 \pm 5 \mathrm{ka}$ obtained here on lavas from the Rombo and Kilema parasitic belts, respectively, are consistent with two successive stages of fissure opening along $\mathrm{N} 150^{\circ} \mathrm{E}$ - and then $\mathrm{N} 160^{\circ} \mathrm{E}$-oriented fracture networks. Assuming that the two linear volcanic alignments formed perpendicularly to the least compressive regional stress operating at this stage, their varying azimuth should indicate the clockwise rotation $\left(10^{\circ}\right)$ of the regional stress 
field. A quite similar two-phase volcano-tectonic history is documented for the Late Pleistocene-Present evolution of the Chyulu Hills linear volcanic chain further East (Haug and Strecker, 1995).

\section{The Kilimanjaro, a bolt for the EARS magmatic system}

The Kilimanjaro is located in a key area of the EARS, as its central cone construction corresponds to the latest volcanic activity in the southern extremity of the eastern magmatic branch of the EARS. According to the two-steps age evolution proposed in the present study, we can emphasize that the changes in the regional stress field have allowed the maintenance of its activity since recent times (165 ka). Although most of the magmatic activity has stopped in the rest of NKVL, the maintenance of their cone edification for the Kibo and the Meru may be considered as good indicator of the migration toward West of the thermal anomaly under this area (Le Gall et al., accepted). It is worth mentioning that the crust structuring under the volcano has certainly played a key role for its localization. The Kilimanjaro seals a major basement fault intersection, between the NW-SE ASWA shear zone and the northern border of the Masai cratonic area. This feature is certainly one of the major evidence to explain the occurrence of such a large shield volcano in an off-axis position in regards to the global EastAfrican rift propagation. 


\section{Acknowledgments}

Research authorization was provided by the Tanzania Commission for Science and Technology and by Tanzania National Parks. We are indebted to the authorities of Kilimanjaro National Park and to Dr. J. Wakibara for their help to organize our field work in the Marangu area. We thank Pr. S. Muhongo (univ. of Dar Es Saalam) and the French Embassy for their support. All the team is particularly indebted to our Chagga guides R. Mtuy and S. Gaudence, and to all the porters who guide us up to the Kilimanjaro summit. Special thanks are due to E. Makoba (univ. of Dar Es Saalam) and to B. Doerler for climbing with us the 'White Mountain'. Many thanks to J. Rolet and C. Hémond for all their constructive comments and their field support. The present paper was greatly improved thanks to the critical reviews of F. Jourdan and J. Solé. This study was supported by the DyETI program of CNRS-INSU and by a grant of SUCRI (UBO, Brest). Contribution $n^{\circ} 1064$ of the IUEM, European Institute for Marine Studies (Brest, France). Contribution n²376 of the LSCE. 


\section{References}

Ackert, R.A., Singer, B.S., Guillou, H., Kaplan, M.R. and Kurz, M.D., 2003. Cosmogenic ${ }^{3}$ He production rates from ${ }^{40} \mathrm{Ar} /{ }^{39} \mathrm{Ar}$ and $\mathrm{K}-\mathrm{Ar}$ dated Patagonian lava flows at $47^{\circ}$. Earth. Planet. Sci. Lett., 210: 119-136.

Bagdasaryan, G.P., Gerasimovskiy, V.I., Polyakov, A.I. and Gukasyan, R.K., 1973. Age of volcanic rocks in the rift zones of East Africa. Geochem. Int., 10: 66-71.

Baker, B.H., Williams, L.A.J., Miller, J.A. and Fitch, F.J., 1971. Sequence and geochronologyof the Kenya rift volcanics. Tectonophysics, 11: 191-215.

Baker, B.H. and Wohlenberg, J., 1971. Structure and evolution of the Kenya Rift Valley. Nature, 229: 538-542.

Carracedo, J.C., Rodriguez Badiola, E., Guillou, H., Paterne, M., Scaillet, S., Pérez Torrado, F., Paris, R. Fra-Paleo, U. and Hansen A., 2007. The Teide volcan and the rift zones of Tenerife, Canary islands: Eruptive and structural history. Geol. Soc. Am. Bull.(Accepted).

Chadwick, W.W. and Howard, K.A., 1991. The pattern of circumferential and radial eruptive fissures on the volcanoes of Fernandina and Isabela islands, Galapagos. Bull. Volcanol., 53: 259-275.

Charbit, S., Guillou, H. and Turpin, L., 1998. Cross calibration of K-Ar standard minerals using an unspiked Ar measurement technique. Chem. Geol., 150: 147-159.

Chorowicz, J., 1989. Transfer and transform fault zones in continental rifts: examples in the Afro-Arabian rift system. Implications of crust breaking. J. Afr. Earth. Sci., 8: 203214.

Cotten, J., Le Dez, A., Bau, M., Caroff, M., Maury, R.C., Dulski, P., Fourcade, S., Bohn, M. and Brousse, R., 1995. Origin of anomalous rare-earth element and yttrium enrichments in subaerially exposed basalts: evidence from French Polynesia. Chem. Geol., 119: 115-138.

Coussement, C., 1995. Structure transverses et extension intracontinentale. Le rôle des zones de failles d'Assoua et Tanganyika-Rukwa-Malawi dans la cinématique néogène du système Rift Est-Africain. PhD Thesis University of Western Brittany, Brest, 241 pp. 
Dalrymple, G.B. and Lanphere, M.A., 1969. Potassium-Argon dating. Principles techniques and applications to geochronology. W.H. Freeman and company, San Francisco, 251 pp.

Dawson, J.B., 1992. Neogene tectonics and volcanicity in the North Tanzania sector of the Gregory Rift Valley: contrasts with the Kenya sector. Tectonophysics, 204: 81-92.

De Rosa, R., Guillou, H., Mazzuoli, R. and Ventura, G., 2003. New unspiked K-Ar ages of volcanic rocks of the central and western sector of the Aeolian Islands: reconstruction of the volcanic stages. J. Volcanol. Geoth. Res., 120: 161-178.

Downie, C. et al., 1965. Quarter Degree Sheets 42, 56 and 57, Kilimanjaro-Moshi and explanatory notes. Tanzanian Geological Survey, Dodoma.

Downie, C., Humphries, D.W., Wilcockson, W.H. and Wilkinson, P., 1956. Geology of Kilimanjaro. Nature, 178: 828-830.

Downie, C. and Wilkinson, P., 1972. The geology of Kilimanjaro. The Departement of Geology, The University of Sheffield, Sheffield, 253 pp.

Ebinger, C.J., Poudjom Djomani, Y., Mbede, E., Foster, A.N. and Dawson, J.B., 1997. Rifting Archean lithosphere: Eyasi-Manyara-Natron rifts, East Africa. J. Geol. Soc. London, 154: 947-960.

Evans, A.L., Fairhead, J.D. and Mitchell, J.G., 1971. Potassium-Argon ages from the volcanic province of Northern Tanzania. Nature, Phys. Sci., 229: 19-20.

Evernden, J.F. and Curtis, G.H., 1965. The potassium-argon dating of late cenozoic rocks in East Africa and Italy. Curr. Anthropol., 6: 343-385.

Foster, A.N., Ebinger, C.J., Mbede, E. and Rex, D., 1997. Tectonic development of the northern Tanzanian sector of the East African Rift System. J. Geol. Soc. London, 154: 689-700.

Fuhrmann, U., Lippolt, H. and Hess, C.J., 1987. HD-B1 Biotite reference material for K-Ar chronometry. Chem. Geol., 66: 41-51.

Guillou, H., Carracedo, J.C. and Day, S., 1998. Dating the upper Pleistocene - Holocene volcanic activity of La Palma using the Unspiked K-Ar Technique. J. Volcan. Geoth. Res., 86: 137-149. 
Guillou, H., Carracedo, J.C., Paris, R. and Perez Torrado, F.J., 2004a. Implication for the early shield-stage evolution of Tenerife from K/Ar ages and magnetic stratigraphy. Earth Planet. Sci. Lett., 222: 601-616.

Guillou, H., Carracedo, J.C., Pérez Torrado, F. and Rodriguez Badiola, E., 1996. K-Ar ages and magnetic stratigraphy of hotspot-induced, fast grown oceanic island: El Hierro, Canary Islands. J. Volcanol. Geoth. Res., 73: 141-155.

Guillou, H., Maury, R.C., Blai, S., Cotton, S., Legendre, C., Guille, G. and Caroff, M., 2005. Age progression along the Society hotspot chain (French Polynesia) based on new unspiked K-Ar ages. Bull. Soc. Geol. Fr., 176: 135-150.

Guillou, H., Perez Torrado, F.J., Hansen Machin, A.R., Carracedo, J.C. and Gimeno, D., 2004b. The Plio-Quaternary volcanic evolution of Gran Canaria based on new K-Ar ages and magnetostratigraphy. J. Volcanol. Geoth. Res., 135: 221-246.

Guillou, H., Singer, B.S., Laj, C., Kissel, C., Scaillet, S. and Jicha, B.R., 2004c. On the age of the Laschamp geomagnetic excursion. Earth. Planet. Sci. Lett., 227: 331-343.

Guillou, H., Sinton, J., Laj, C., Kissel, C. and Szeremeta, N., 2000. New K-Ar ages of shield lavas from Waianae Volcano, Oahu, Hawaiian Archipelago. J. Volcanol. Geoth. Res., 96: $229-242$.

Haug, G.H. and Strecker, M.R., 1995. Volcano-tectonic evolution of the Chyulu Hills and implications for the regional stress field in Kenya. Geology, 23(2): 165-168.

Hautmann, H.J. and Lippolt, H., 2000. ${ }^{40} \mathrm{Ar} /{ }^{39} \mathrm{Ar}$ dating of central European K-Mn oxides, a chronological framework of supergene alteration processes during the Neogene. Chem. Geol., 170: 37-80.

Hess, C.J. and Lippolt, H., 1994. Compilation of K-Ar measurments on HD-B1 standard biotite. In: G.S. Odin (Editor), Phanerozoic Time Scale Bull. Liais. Inform. I.U.G.S., Subcom. Geochronol., pp. 19-23.

Kelley, S., 2002. Excess argon in K-Ar and Ar-Ar geochronology. Chem. Geol., 188: 1-22.

Laughlin, A.W., Poths, J., Healey, H., Reneau, S. and WoldGabriel, G., 1994. Dating of quaternary basalts using the ${ }^{3} \mathrm{He}$ and ${ }^{14} \mathrm{C}$ methods with implications for excess ${ }^{40} \mathrm{Ar}$. Geology, 22: 135-138. 
Le Bas, M.J., Le Maitre, R.W., Streckeisen, A. and Zanettin, B., 1986. A chemical classification of volcanics rocks based on the total-alkali-silica diagram. J. Petrol., 27: 745-750.

Le Gall, B., Nonnotte, P., Rolet, J., Benoit, M., Guillou, H., Mousseau-Nonnotte, M., Albaric, J. and Deverchère, J. Rift propagation at craton margin. Distribution of faulting and volcanism in the North Tanzanian Divergence (Est Africa) during Neogene times. Tectonophysics, doi:10.1016/j.tecto.2007.11.005, in press.

MacIntyre, R.M., Mitchell, J.G. and Dawson, J.B., 1974. Age of fault movements in Tanzanian sector of East African Rift System. Nature, 247: 354-356.

Manega, P.C., 1993. Geochronology, geochemistry and isotopic study of the Plio-Pleistocene hominid sites in the Ngorongoro volcanic Highland in northern Tanzania. PhD thesis, University of Colorado.

Odin, G.S., et al., 1982. Interlaboratory standards for dating purposes. In: G.S. Odin (Editor), Numerical Dating in Stratigraphy. John Wiley \& Sons, New York, pp. 123-158.

Osmaston, H.A. and Harrison, S.P., 2005. The late Quaternary glaciation of Africa: A regional synthesis. Quatern. Int., 138-139: 32-54.

Renne, P.R., Swisher, C.C., Deino, A.L., Karner, D.B., Owens, T.L. and De Paolo, D.J., 1998. Intercalibration of standards, absolute ages and uncertainties in ${ }^{40} \mathrm{Ar} /{ }^{39} \mathrm{Ar}$ dating. Chem. Geol., 145: 117-152.

Saggerson, E.P., 1963. Geology of the Simba-Kibwesi area, 58. Geological Survey of Kenya Report, $70 \mathrm{pp}$.

Scaillet, S. and Guillou, H., 2004. A critical evaluation of young (near-zero) K-Ar ages. Earth. Planet. Sci. Lett., 220: 265-275.

Shanahan, T.M. and Zreda, M., 2000. Chronology of Quaternary glaciations in East Africa. Earth. Planet. Sci. Lett., 177: 23-42.

Singer, B.S., Ackert, R.P.J. and Guillou, H., 2004. ${ }^{40} \mathrm{Ar} /{ }^{39} \mathrm{Ar}$ and K-Ar chronology of Pleistocene glaciation in Patagonia. Geol. Soc. Am. Bull., 116: 434-450.

Spell, T.L. and McDougall, I., 2003. Characterization and calibration of ${ }^{40} \mathrm{Ar} /{ }^{39} \mathrm{Ar}$ dating standards. Chem. Geol., 198: 189-211. 
Steiger, R.H. and Jäger, E., 1977. Convention on the use of decay constant in geo- and cosmochronology. Earth. Planet. Sci. Lett., 36: 359-362.

Villa, I.M., 1991. Excess argon in potassic volcanites. Schweizeriche mineralogische un petrographische mitteilungen, 71: 205-209.

Walker, G.P.L., 1999. Volcanic rift zones and their intrusion swarms. J. Volcanol. Geoth. Res., 94: 21-34.

Wilkinson, P., Mitchell, J.G., Cattermole, P.J. and Downie, C., 1986. Volcanic chronology of the Meru-Kilimanjaro region, Northern Tanzania. J. Geol. Soc. London, 143: 601-605.

Wolff, J.A., 1985. Zonation, mixing and eruption of silica-undersaturated alkaline magma: a case study from Tenerife, Canary Islands. Geol. Mag., 122: 623-640. 


\section{Figure captions}

Fig. 1. Sketch structural map of the transition zone between the South Kenya rift and the North Tanzanian Divergence. Note the location of Mount Kilimanjaro at the eastern end of the transverse volcanic belt (NKVB: Ngorongoro-Kilimanjaro Volcanic Belt). H: Hanang, Kw: Kwaraha, L: Loolmalasin, LS: Lemagrut-Sadiman, N: Ngorongoro, O: Olmoti; E: Empakai, G: Gelai, K: Ketumbeine, Es: Essimingor, B: Burko, TM: Tarosero-Monduli, M: Mt Meru, S: Shira, K: Kibo, Mz: Mawenzi, C.H.: Chyulu Hills; Ey: Eyasi basin, Ma: Manyara basin, NRV: Natron Rift Valey, ED: Engaruka depression; P: Pare mountains. Inset: location of the North Tanzanian volcanic province at the Southern extremity of the Eastern branch of the East African rift system.

Fig. 2. A, SRTM (Shuttle Radar Topography Mission) digital elevation model of Kilimanjaro (lateral resolution: $90 \mathrm{~m}$, vertical resolution: $16 \mathrm{~m}$, no vertical exaggeration) showing the main morphotectonic features. The trace of faults inferred to have controlled the linear parasitic belts is drawn. B, Simplified geological map of the three volcanic centres of Mount Kilimanjaro (modified after Downie et al., 1965), with the localisation of the samples and the corresponding K-Ar Unspiked ages (ka). 1. Main volcanic units (this study), 2. Original volcanostratigraphic nomenclature from Downie et al. (1965).

Fig. 3. Total-alkalis-silica (TAS) diagram illustrating the range of petrological compositions for lavas erupted on the three centres and from the parasitic activity of the Mount Kilimanjaro (unpublished data). The fields are from Le Bas et al. (1986).

Fig. 4. Selected thin-sections photographs (cross-polarized light x 40) of intrusive lithologies and lavas from Mount Kilimanjaro main volcanic formations. A, 05KI08B: intrusive basanitic sample with doleritic texture from Shira Ridge group. B, 05KI45: intrusive trachybasalt with finely crystallized groundmass from the important dyke swarm of the Neuman Tower-Mawenzi group. C, 05KI14: phono-tephrite from Lava Tower group with tabular phenocrysts of Na-feldspar. D, 05KI20: phonolitic lava from Rhomb Porphyry group with mega-phenocrysts (30-40 mm long) of Na-feldspar (upper left corner) and olivine phenocrysts. The groundmass is composed of nepheline 
microcrysts and K-feldspar microliths. E, 05KI30: aphyric phonolite from Lent group with microcrysts of amphibole in a microlithic groundmass of K-feldspars. F, 05KI12: phonolite from Caldera Rim group with mega-phenocrysts of Na-feldspars and scarce nepheline phenocrysts. G, 05KI22: aphyric phonolite from Inner Crater group with olivine microcryst and K-feldspars microliths. H, Sample 03TZ42B from late parasitic activity. Basanite with olivine and zoned clinopyroxene phenocrysts.

Fig. 5. Characteristic volcanic features of Mount Kilimanjaro. A, Basanitic dyke $\left(\mathrm{N} 95^{\circ} \mathrm{E}\right.$ $75^{\circ} \mathrm{S}, 1,50 \mathrm{~m}$ thick) of the Shira radial swarm, intruding pyroclastic breccias of the Shira Ridge group. B, Trachybasaltic dyke $\left(\mathrm{N} 90^{\circ} \mathrm{E} 55^{\circ} \mathrm{S}, 1 \mathrm{~m}\right.$ thick) from the mafic swarm of the Mawenzi eruptive centre. C, Prismatic lava flow of phonolite from Caldera Rim group, erupted from the 'Lava Tower' protrusion and emplaced on eroded sequences of the Lava Tower group ('Great Barranco' valley). D, Strombolian tuff cones emplaced during the final parasitic stage on the upper slopes of the Rombo zone.

Fig. 6. Chronology of volcanic and tectonic events for the three magmatic centres of Mount Kilimanjaro. The time scale is enlarged for the period $0.5 \mathrm{Ma}$ - Present to better characterised the polyphased volcanicity of the Kibo central edifice.

\section{Table caption}

Table 1. Main geological characteristics and K-Ar ages for samples from Mount Kilimanjaro. Intrusive facies and lavas were named using the Total-Alkali-Silica (TAS) discrimination diagram of Le Bas et al. (1986). Age calculations are based on the decay $\left(\lambda_{\varepsilon}=0.581 \times 10^{-10} \mathrm{yr}^{-1}, \lambda_{\beta}=4.963 \times 10^{-10} \mathrm{yr}^{-1}\right)$ and abundance constants from Steiger and Jäger (1977). Standards used include LP-6 (127.8 \pm 0.7 Ma: Odin et al., 1982) and HD-B1 (24.21 \pm 0.32 Ma: Fuhrmann et al., 1987; Hess and Lippolt, 1994; Hautmann and Lippolt, 2000). At the 95\% confidence level, the values adopted here are consistent with those obtained for several ${ }^{40} \mathrm{Ar} /{ }^{39} \mathrm{Ar}$ standards intercalibrated against biotite GA-1550 (Renne et al.,1998; Spell and McDougall, 2003). 


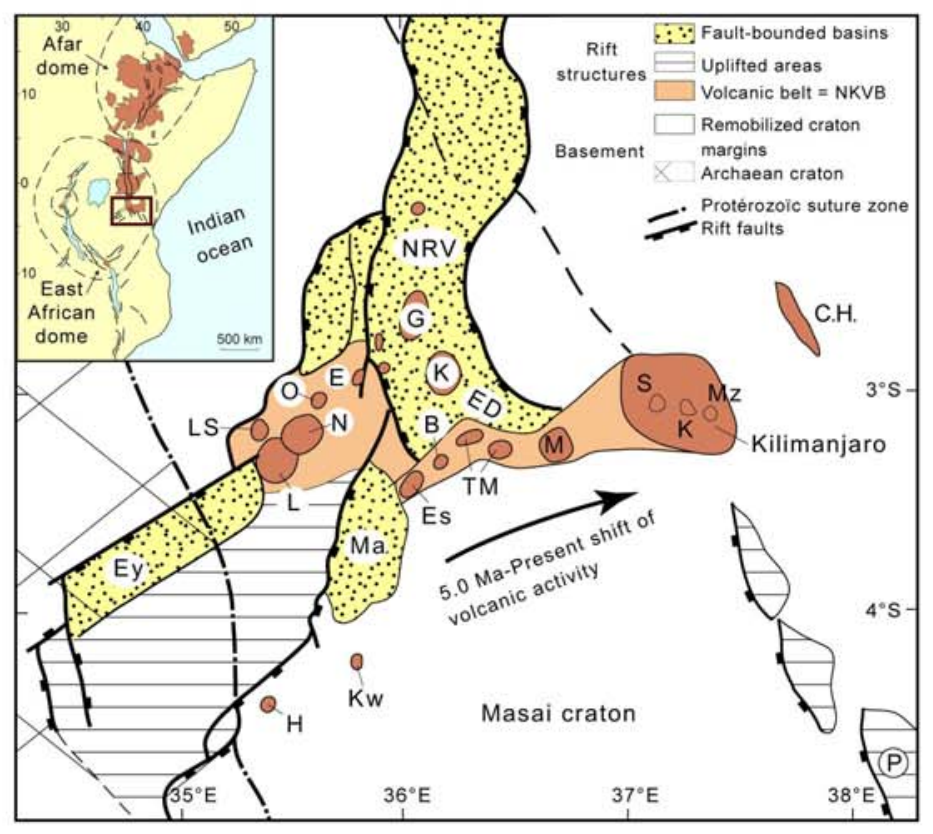

Figure 1 


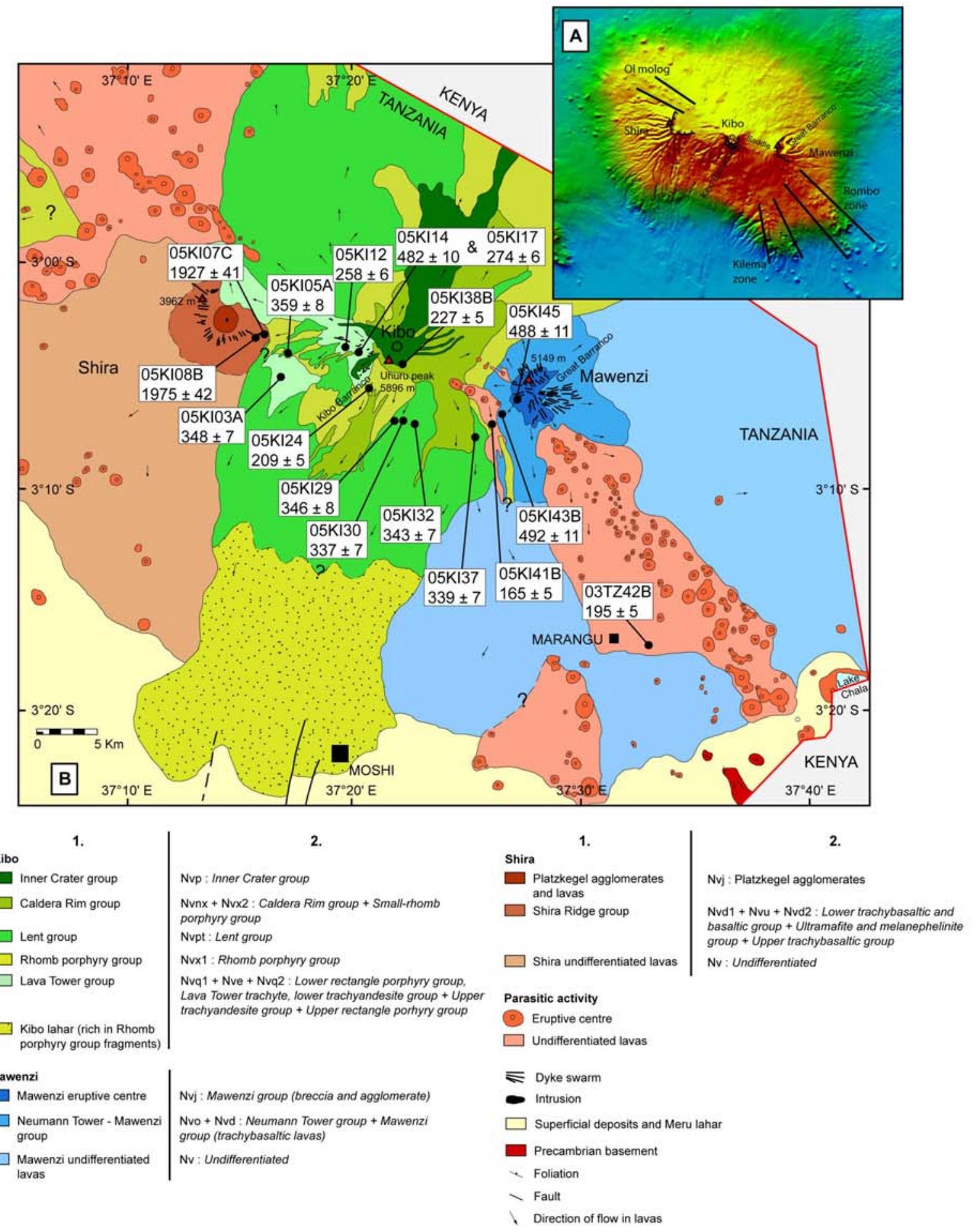

Figure 2 


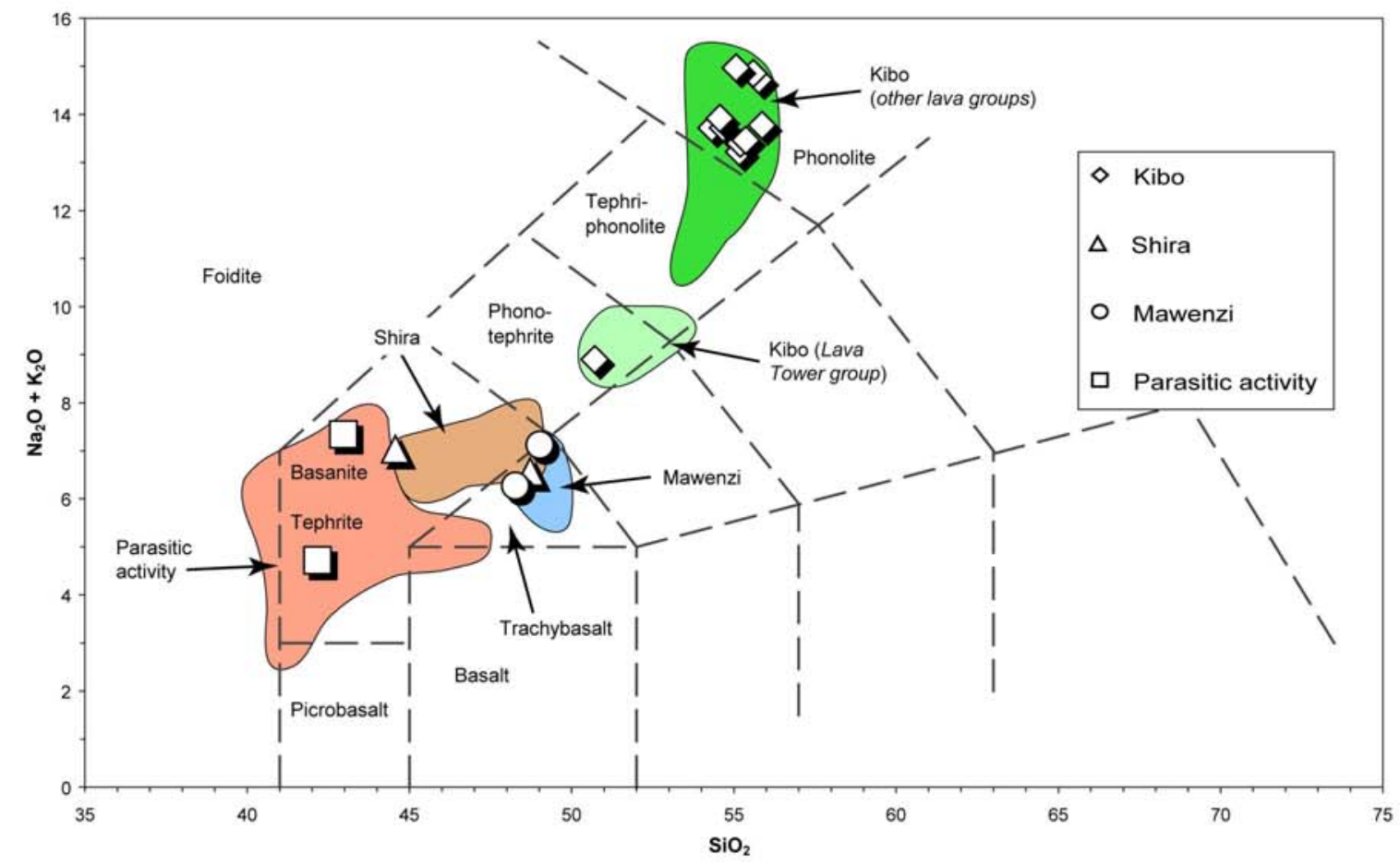

Figure 3 


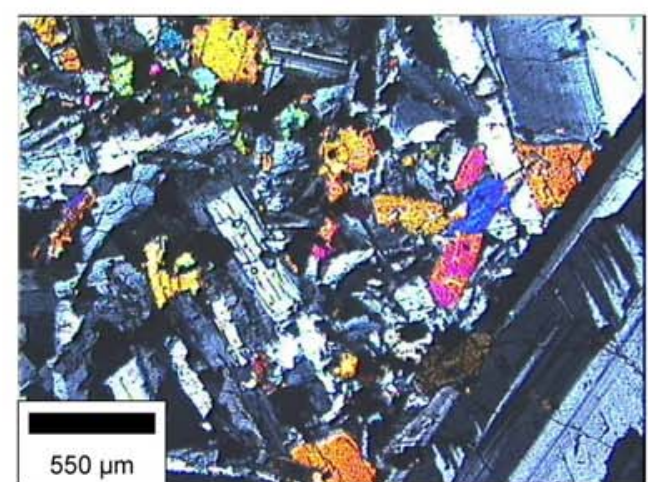

A

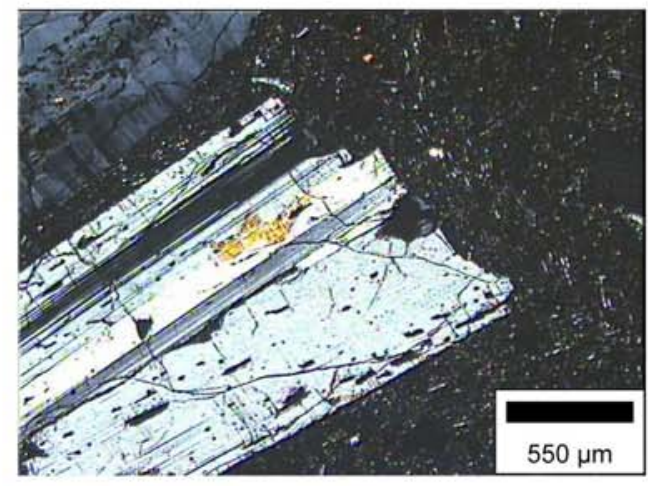

C

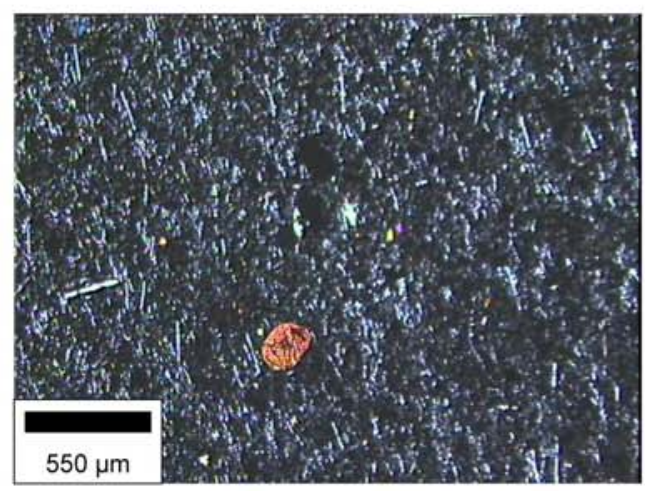

E

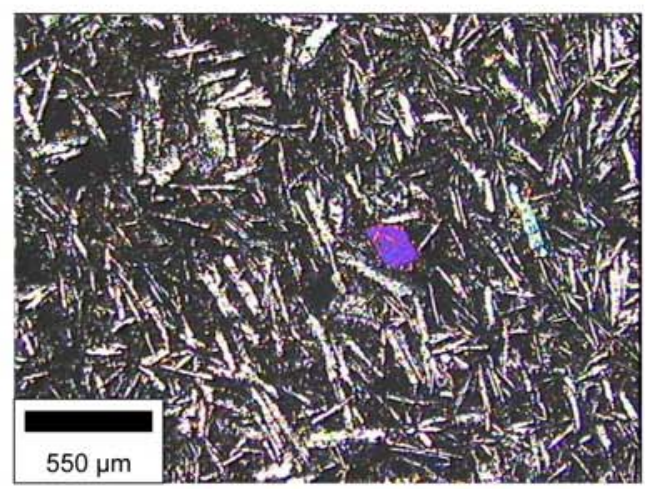

G

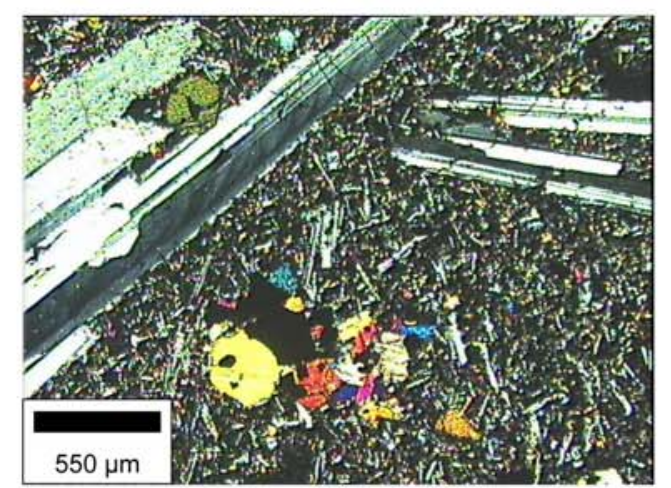

B

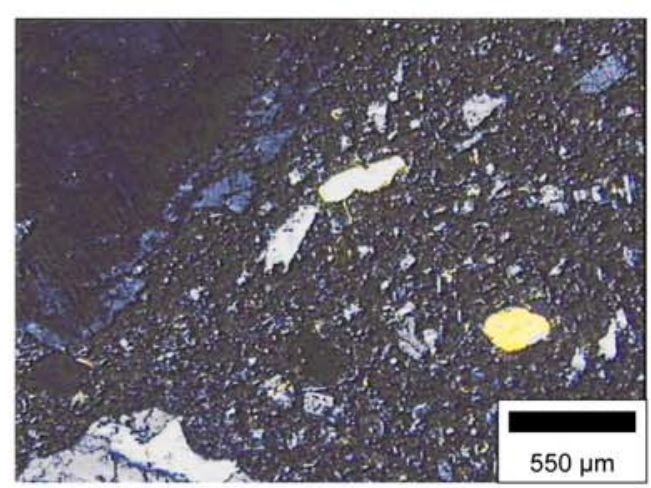

D

Figure 4

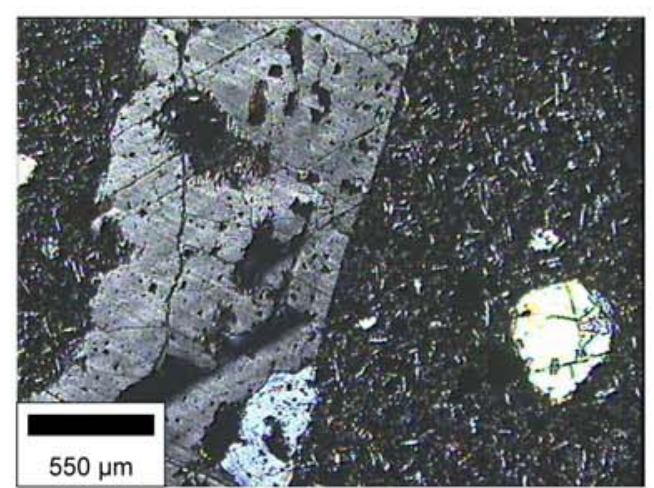

F

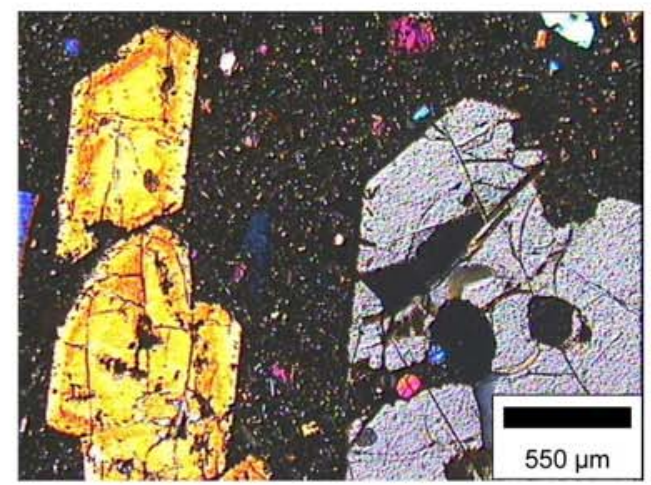

$\mathrm{H}$ 


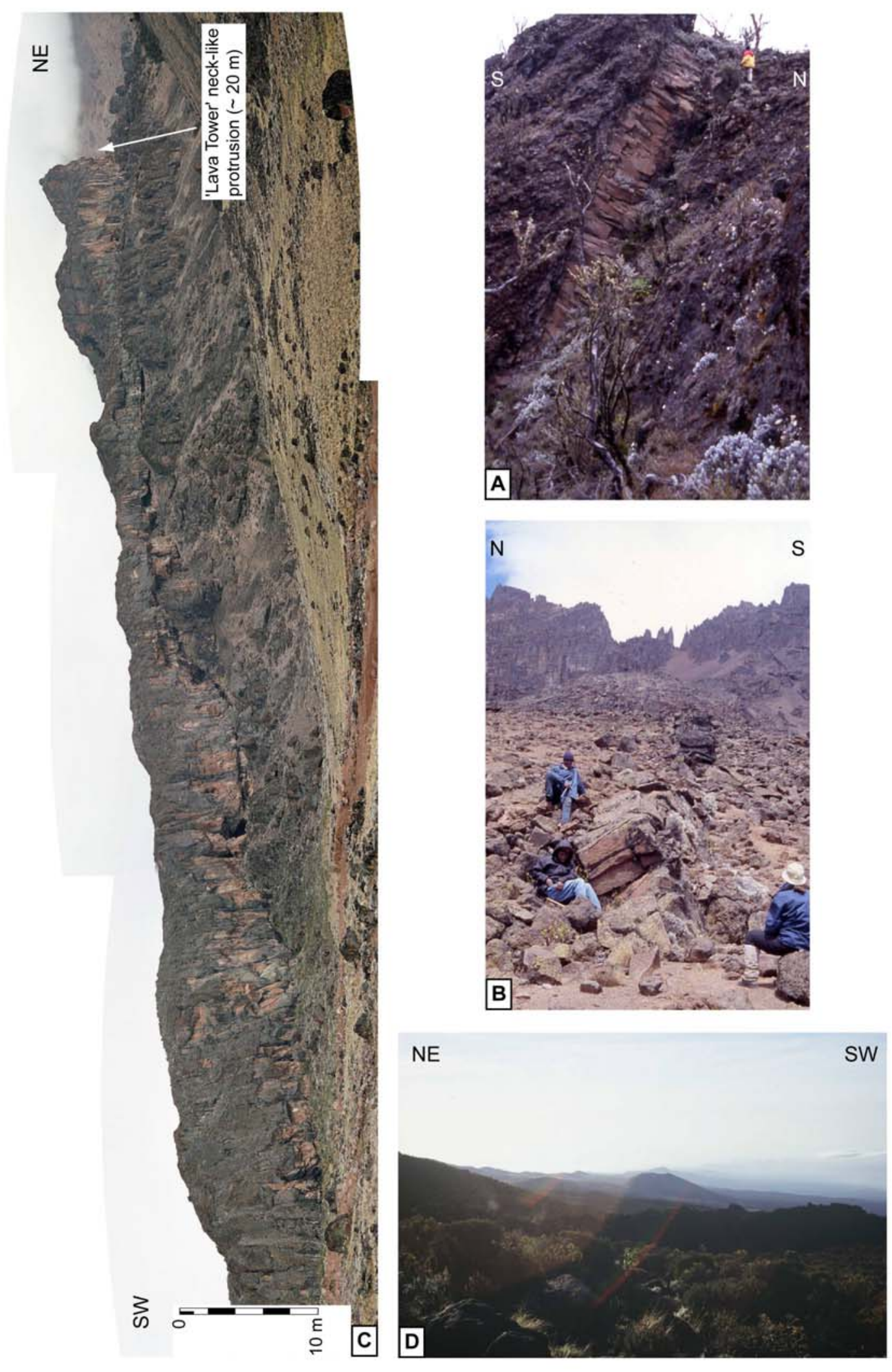

Figure 5 

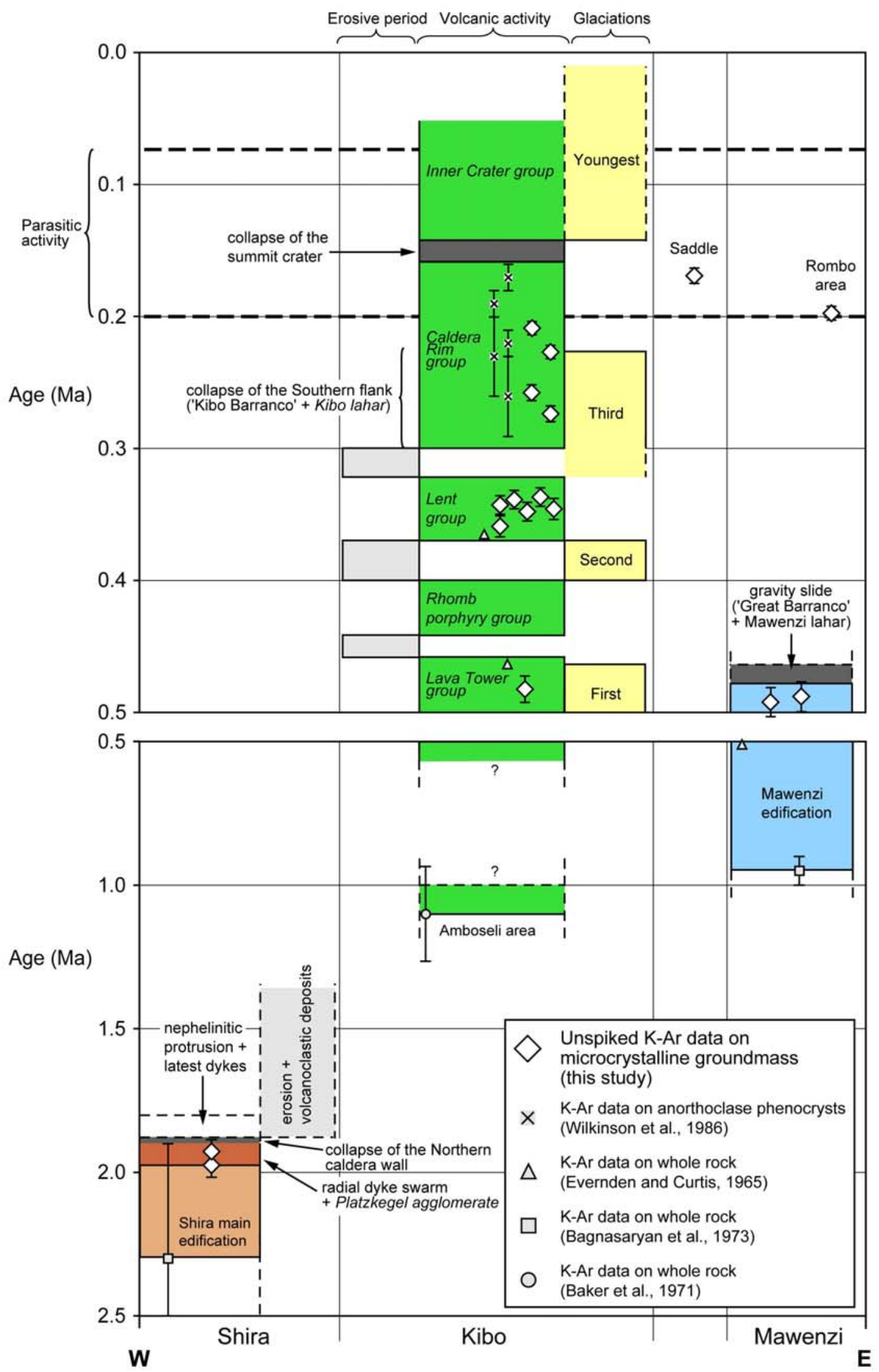

Figure 6 


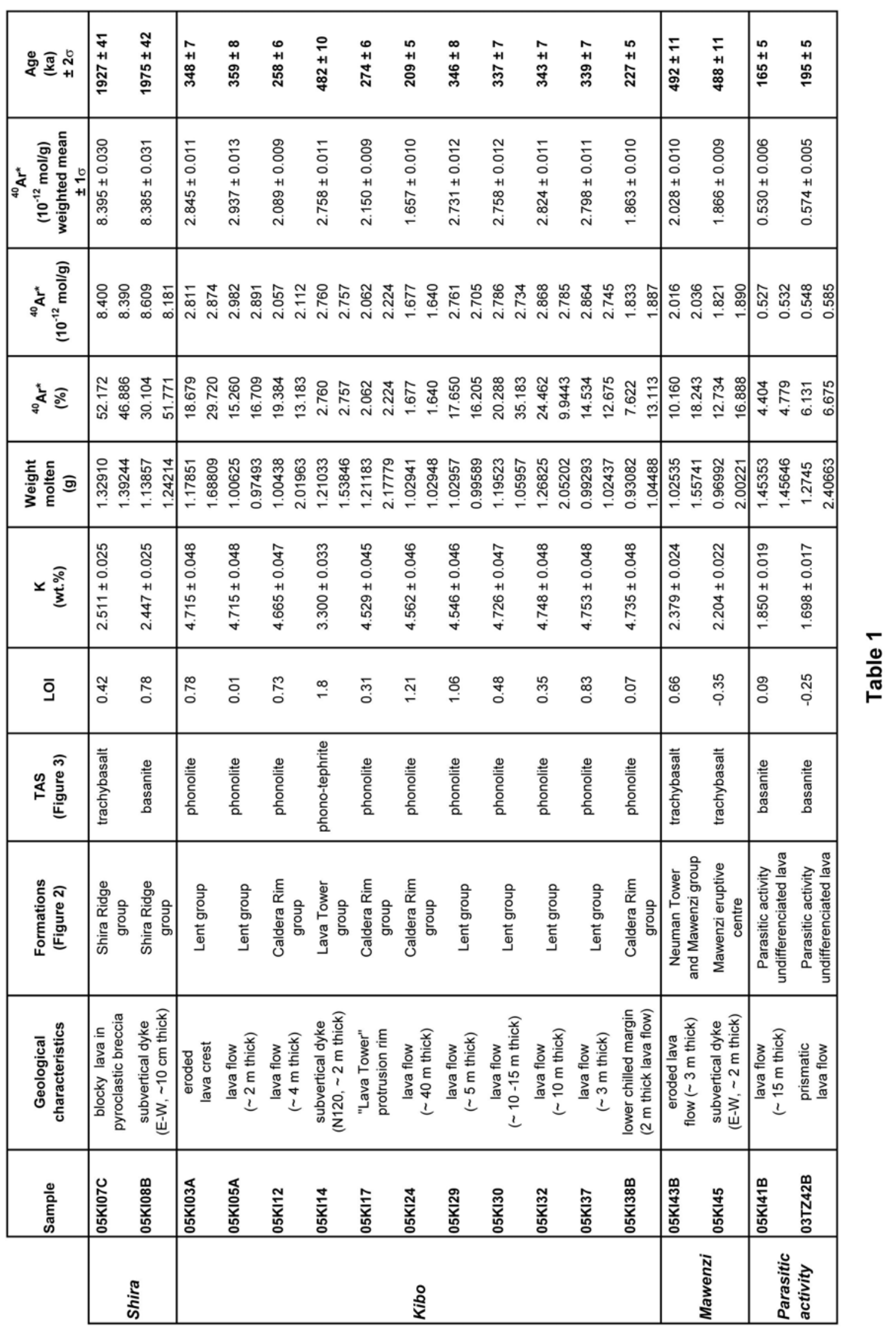

